\title{
How Rome Enabled Impersonal Markets
}

\author{
Benito Arruñada*
}

This version: March, 2016

\begin{abstract}
Impersonal exchange increases trade and specialization opportunities, encouraging economic growth. However it requires the support of sophisticated public institutions. This paper explains how Classical Rome provided such support in the main areas of economic activity by relying on public possession as a titling device, enacting rules to protect innocent acquirers in agency contexts, enabling the extended family to act as a contractual entity, and diluting the enforcement of personal obligations which might collide with impersonal exchange. Focusing on the institutions of impersonal exchange, it reaches a clear positive conclusion on the marketfacilitating role of the Roman state because such institutions have unambiguously positive effects on markets. Moreover, being impersonal, these beneficial effects are also widely distributed across society instead of accruing disproportionately to better-connected individuals.
\end{abstract}

Keywords: property rights, enforcement, transaction costs, Roman law, impersonal exchange, personal exchange, New Institutional Economics, Law and Economics.

JEL: D1, D23, G38, K11, K12, K14, K22, K36, L22, N13, O17, P48.

\footnotetext{
* Pompeu Fabra University and Barcelona GSE. E-mail: benito.arrunada@upf.edu. This work has benefitted from advice and comments received from the editor, Ran Abramitzky, two anonymous reviewers, Maria Brosius, Yun-chien Chang, Giusseppe Dari-Matiacci, Damián Fernández, Stephen Hansen, François Lerouxel, Joe Manning, Fernando P. Méndez, Pedro Pernas, Leandro Prados de la Escosura, Dominic Rathbone, Jane Rowlandson, Carlos Sánchez-Moreno Ellart, Carlos Serrano, Peter Temin, Rick Verhagen, Hans-Joachim Voth, and participants at numerous presentations. Usual disclaimers apply. It received support from the Spanish Ministry of the Economy and Competitiveness, through grant ECO2014-57131-R.
} 


\section{Introduction}

The extensive markets that developed in the late Republic and early Roman Empire relied on types of impersonal exchange that required substantial institutional support. How did the Romans provide such support? What specific solutions did they adopt? Were institutions created ex novo or adapted from previous ones? Were these institutions part of a private or a public order? Lastly, do they give us any clue as to the role played by Ancient states and, in particular, the Roman state with respect to their market economies? These are some of the main questions that this paper explores. In tackling them, I aim to clarify the nature and extent of the market economy in Classical Rome and the role of the Roman state in facilitating the market economy.

At its peak, the Roman economy showed many signs of impersonal exchange, including urbanization, long-distance trade, specialization, and even some degree of market integration. Reaching such a level of impersonality required substantial institutional support. This was provided by the Roman state mainly by: (1) developing additional judicial actions and nuanced legal concepts that effectively distinguished between personal and real (and, therefore, impersonal) rights; (2) introducing new conveyancing and titling solutions based on legal possession and public knowledge, which superseded the primitive ceremonial transfers that were no longer suitable for distant markets with a large number of unknown parties; (3) modifying formal rules that were in conflict with impersonal exchange, in order to facilitate contractual agency and limit self-help, thus developing solutions which were functionally close to those operating in modern times; (4) co-opting traditional legal structures, mainly those dealing with marriage, adoption and slavery, thus enabling the extended family to act as an effective contractual entity, and achieving many of the benefits that the modularity of modern firms provides today; and (5) sustaining and adapting specific public organizations, mainly civil registries, which made clear who was a family member, as well as, in some provinces, land and mortgage registries which were organized to reduce private transaction costs, as indicated by the unprivileged status granted to tax duties.

The main contribution of this paper is to provide, within a coherent analytical framework, a novel interpretation of these institutions, complementing the current discussion in Ancient History on the role of the state in the market economy. In particular, it has been questioned whether the Roman state favored the development of the market or merely pursued extractive objectives that were conducive, as an unintentional byproduct, to the development of market exchange. According to this latter view, Roman markets were not supported by the state and only worked in a limited manner within the informal networks of merchants and households (e.g., Bang 2008). I, however, argue that Roman institutions evolved to protect the interests of market participants outside such personal networks, especially when they had little personal knowledge of one another. In short, the Roman state did facilitate impersonal exchange, the hallmark of developed markets and an important element of open societies.

This positive assessment of the market-enabling role of the Roman state complements the existing literature in several dimensions. First, instead of using quantitative indicators on how 
markets functioned, such as price uniformity (Temin 2013:27-91), it evaluates the quality of institutions, a variable more directly linked to state action. Second, instead of analyzing state interventions with doubtful effects on markets, such as the rules on speculators and large producers analyzed by Lo Cascio (forthcoming), the paper focuses on institutions that indisputably reduce transaction costs, expanding markets and specialization. Moreover, instead of focusing on state actions that were likely to mostly benefit members of the elite, such as the rules on mandate analyzed by Kehoe (forthcoming), it studies the institutions enabling impersonal exchange, which likely benefit all members of society more equally.

The rest of the paper develops these arguments as follows. The next section reviews and discusses some empirical indicators of market development that support the idea that the Romans were able to sustain impersonal exchange, at least in some markets and transactions. The subsequent sections explain the main institutions they used to achieve this. First, they analyze how the Romans made impersonal exchange possible in the areas of property (section 3) and business (section 4). Then, section 5 considers how they enforced personal obligations, avoiding interference with impersonal exchange. Section 6 concludes. ${ }^{1}$

\section{Impersonal exchange in the Roman economy}

The Roman economy was preindustrial but, at least for our period of interest, ${ }^{2}$ it offers many indicators of impersonal exchange, such as high rates of urbanization, remarkable productive specialization, substantial market integration for at least some products, and extensive and sophisticated financial markets. ${ }^{3}$

${ }^{1}$ Two cautions on the focus and the expositional strategy adopted in the paper. First, given my focus on impersonal exchange, I will not analyze factors and institutions making all types of market exchangeboth personal and impersonal — and, in particular, long-distance trade viable, such as the effective provision by the Roman state of: a stable currency; a tolerable tax burden and little government intervention; peace and security of property in a wide geographical area, with, e.g., little piracy in the Mediterranean; and a hybrid but comprehensive judicial system which, without destroying local legal systems, covered the whole of the Empire through potential appeals to Rome. Second, while the main text is intended to be accessible without specialized knowledge of Roman or legal institutions, the footnotes discuss narrower issues and make greater use of Latin and legal terms.

2 This includes the last two centuries of the Republic and up to the second half of the third century C.E. Even if markets and prosperity survived in many parts of the Empire into the fourth and fifth centuries (e.g., Heather 2005 and Ward-Perkins 2005), the market economy was seriously damaged by the third century C.E., with the collapse of frontiers and other events, such as the doubling in size and cost of the army, the increase in taxation, the emergence of a new, more militaristic and local ruling class, and the rise of Christianity (Brown 1971).

${ }^{3}$ Moreover, the Roman economy was well developed not only in terms of size and specialization but also in the predominant role of market exchange for allocating all types of resources, even some which modern societies are reluctant to treat commercially. In addition to a market for slaves that had little in common with "closed" slavery (Scheidel 2008, Temin 2013:114-38), there was an active market for the 
A modern estimate of urbanization rates for the Empire in mid second century C.E. ranges between 7.4\% and 19.5\% (Wilson 2011:191-93), comparable to those of leading European countries between 1600 and 1750. These numbers suggest substantial specialization, which took place mainly in agricultural production and processing industries, and enabled technological change and diffusion (Greene 2000). From the second century B.C.E., different provinces had specialized in producing different types of goods, so that Italy exported wine and oil; Egypt, grain; Spain, wine, oil and minerals; North Africa, grain and oil (de Vos 2013). Long-distance trade in bulk commodities was prevalent (Temin 2006), and the degree of specialization achieved in them suggests that the difficulties for impersonal exchange were overcome at least in those markets. Documentary evidence also shows that at least the large estates were organized with the aim of reaching economies of scale and producing marketable surpluses (Rathbone 1991). Moreover, the city of Rome, far from being an extractive parasite, as Finley (1999) contended, specialized in producing and exporting all sorts of services (Ellickson, forthcoming).

It has even been argued that the Roman economy was not merely a collection of independent local markets but an integrated market economy, as "markets for goods, labor and capital were relatively well developed in ancient Rome, which in turn encouraged specialization and efficiency. These markets were able to work well in the environment created by public authorities who provided local public services in cities and a functional rule of law across most of the Empire" (Temin 2006:137). In particular, "the market for land in the Roman Empire worked approximately like the land market today" (Temin 2013:139) because land was typically held in fee simple with few impediments to land usage and sale. The market in urban real estate enjoyed not only a substantial provision of public goods but, compared with other ancient societies, much less interference from public authorities in terms of debt moratoria, rent control, mandatory redemption and tenant protectionism (Ellickson, forthcoming:42-45). In addition, prices varied substantially and transactions were sophisticated, including mortgages and subdivisions.

Similarly, financial intermediaries and transactions were also sophisticated, and bankers provided such an array of services (Andreau 1999) that it has even been suggested that "financial institutions in the early Roman Empire were better than those of eighteenth century France and Holland" (Temin 2013:189). Moreover, much, or even most borrowing, according to some authors (e.g., Johnston 1999:84), was for commercial purposes, and financial markets in different regions of the Empire were linked, most likely through financial intermediaries (Temin 2013:178-79). Credit was also so abundant that indebtedness was often considered a problem (Crook 1967:171-72). Lastly, if interest rates, "perhaps the most evident quantitative dimension of the efficiency of the institutional framework" (North 1990:69), were indeed not much higher than those of today (Crook 1967:211), this would suggest low default risk and therefore effective guarantees. And, despite usury regulations, market participants were able to adjust the interest rate to the risk of the loan. ${ }^{4}$

rights to sue or to inherit (Riggsby 2010:127), and money compositions were acceptable even for criminal acts (Nicholas 1962:209).

${ }^{4}$ Rates were often regulated via usury ceilings, but they were also often evaded by, e.g., lending to nonRoman citizens (Livy 2004, 35:7), not stating the rate in the contract, and possibly granting hidden discounts on the principals (Verboven 2003). In fact, "repeated statutes were made, for obviating all elusions, which by whatever frequent expedients repressed, were yet through wonderful devices still 
True, the extent and nature of market exchange in ancient economies, and that of Rome in particular, remain controversial. ${ }^{5}$ In particular, market integration is subject to numerous caveats (e.g., Erdkamp 2005, Bransbourg 2012). It has also been debated to what extent most production actually remained local, with most long-distance trade taking place only by water, given the higher costs of transporting goods over land (Scheidel 2013). This would sustain the presence or even predominance of customary systems in many rural areas. Impersonal exchange might have been limited to some markets and transactions, and doubts remain on the nature of exchanges. For instance, for rural land in Roman Egypt, Rowlandson (1981) considers that many of the transactions she analyzes took place between relatives, which are more likely to be personal.

However, for a land market to exist it is not necessary for most land to be transferred by purchase, as Temin points out (2013:144). Moreover, the evidence is at least open to diverse interpretations as to what extent exchange was personal or impersonal and in which transaction attributes or dimensions. This is the case in the crucial area of sureties, where it is widely believed that the abundant supply of credit to the dominant class was structured as a web of loans and personal sureties, in a circular fashion, relying on friendship but based, deep down, on the supposedly secure market for land (Crook 1967:170-72). This reliance on real rights suggests that allegedly personal credit was in fact grounded on secured and therefore impersonal credit. In fact, complex interaction between personal and impersonal mechanisms is not unique, as I will examine below.

\section{Impersonal exchange in property}

Durable assets such as land are the most suitable objects for impersonal exchange, not only for the actual transfer of the assets but also for trading partial rights on them (e.g., a lease) or using them as collateral for credit. This use of land as collateral also provides the clearest example of impersonality: with an enforceable mortgage, the creditor will at worst be paid from the land itself. Therefore, with a mortgage, credit can be contracted without knowing the personal characteristics of the debtor. However, this example also illustrates the need for institutional support for the mortgage to be valid and valuable: the person granting the mortgage

springing up afresh" (Tacitus 2005, Annals 6.16). In the light of usury-avoidance practices (Koyama 2010), the prevalence in the ancient evidence of loan contracts stating the regulated and legallyenforceable maximum rate of $12 \%$ or no rate at all (e.g., Lerouxel 2012b), irrespective of the debtor's default risk, suggests that the effective implicit rate-easily disguised by, e.g., discounting the loaned amount below the stated principal — was probably higher. Similarly, in the opposite direction, the Sulpicii archive also provides a basis for believing that variable interest rates below the legal limit were charged (Bransbourg 2014).

5 Judgments on ancient economies must always be taken cautiously, given the lack of adequate evidence. See, for instance, Scheidel (2012:2-5), for a summary of the limitations for unambiguously interpreting the evidence on the Roman economy, and Scheidel and Friesen (2009) for a comparative assessment of works obtaining substantially different estimates of the size of the Roman economy. 
must be the land owner, and the debtor must be assured that the asset is not burdened by any previous and therefore prevailing mortgage.

\subsection{The problem of impersonal exchange}

In personal exchange, parties trade rights and duties with respect to each other. To protect themselves, they need to ascertain how likely their potential counterparties are to fulfill their obligations, which leads them to gather information on their wealth, reputation and moral traits. ${ }^{6}$ By contrast, in impersonal exchange, such as in the mortgage example, parties trade real rights directly linked to assets, so that their value is independent of the personal characteristics of sellers. This provides valuable enforcement, especially for immovable assets. ${ }^{7}$

Therefore, all types of buyers want to acquire a right on the traded asset itself, a real right, instead of a less valuable personal claim against the selling agent. They want to enjoy priority over any other rightholder, including previous owners. In consequence, impersonal exchange has a sequential structure: it involves at least three parties to, at least, two interacting transactions. The three parties are the "principal" (using a general term to refer to the owner or rightholder on the relevant asset), the selling "agent," and the buyer. ${ }^{8}$ There are always at least two transactions because there must be a previous or "originative" transaction by which the principal "authorizes" the agent before the agent sells to the buyer in a "subsequent" transaction. ${ }^{9}$

Real rights clearly enjoy valuable enforcement advantages. However, a tradeoff emerges because trading real rights also poses additional information asymmetries and causes specific externalities. In particular, buyers of assets and, in general, acquirers of rights such as mortgages must be sure about the identity of the owner and whether any charges are attached to the asset. Even when it is the owner who is selling property, the buyer may well doubt that the seller is really the owner, or may suspect that, contrary to the seller's assertion that the property is free of

6 This is necessary even under effective and impartial judicial enforcement, to avoid ending up insolvent. Compare this with the view of impersonal exchange as that which takes place in the shadow of an independent court (North 1990:34-35) or with the other views of impersonality summarized in Arruñada (2012:15-18).

7 The key legal difference here is between what in property law are characterized as "personal" (i.e., "contractual" or in personam) rights versus "real" ("property" or in rem) rights. A similar difference arises in business and corporate contexts, where a parallel distinction is often made, but framed in more general terms: not in terms of rights but in terms of priority among creditors. For a more detailed analysis of the problem, see the first section of Arruñada (forthcoming) or, more generally, Arruñada (2012:1542).

8 These names may be deceptive. Note that buyers may see true owners as mere agents and, for durable assets, current owners are yesterday's buyers. Moreover, imagine an owner who, after mortgaging his land, sells it to a buyer claiming that it is free of mortgages. When misbehaving in such a way, the owner of the mortgaged land would be acting as a (bad) agent of the mortgagee, who would be considered the principal.

9 This originative transaction may be implicit, as often happens with previous sales with respect to later sales of durable assets. 
liens, it is instead burdened with opposing rights held by others, such as mortgages or even ownership claims.

Moreover, the possibility of hidden charges reduces the value of all assets, not only of those actually burdened with such charges. For example, if judges enforce secret mortgages on land, buyers of any parcel of land will be reluctant to buy, which will reduce the value of all parcels. Furthermore, given the difficulties inherent in safeguarding the interests of third parties, containing such externalities is impossible without the support of public-ordering institutions (Arruñada 2016).

These institutions must perform a seemingly simple function: make the authorizing transaction between principal and agent verifiable by judges and known by buyers, so that owners cannot opportunistically renege on their decisions, judges can rule efficiently, and buyers can buy safely. Supplying such institutions is no trivial matter, however, as it requires at least replacing rules which, for centuries, have been suitable for personal exchange. It is less difficult when transactions produce, as an unintentional byproduct, publicly observable consequences which can be relied upon for verification. But it is harder when the corresponding transaction may remain hidden to market participants. This is what happens with mortgages, which, in the absence of land registries, may well remain secret, as opposed to possessory rights, which, whatever the institutions, are easier to observe.

\subsection{The Roman solutions}

In this context, it is remarkable that the Roman law of property developed a variety of concepts, rules and procedures to support transactions of real rights on land, enabling asset-based impersonal exchange. Moreover, these solutions changed substantially over time in parallel with changes in the economy and, in particular, with the expansion of long-distance trade.

Early on, Roman law distinguished between two types of assets, providing specific treatment for rights held on the most durable and valuable assets, such as land, slaves and cattle, for which it required a formal and public conveyance, through either a collusive proceeding before the court or a public ceremony known as mancipatio. ${ }^{10}$ Given their value and durability, such assets were more suitable for enforcing multiple real rights. For this reason, it made sense for the law to

10 These durable assets were called res mancipi as they were transferred by either in iure cessio (before the court) or more commonly mancipatio, the public ceremony in which the seller and the acquirer appeared upon the property before a person holding a scale and five witnesses. The acquirer then declared the property to be his, struck a token coin against the scales and handed it to the seller, who said nothing. The ceremony had two main consequences. First, it triggered the start of a prescription period that can also be understood as a purging procedure, as explained below. Contradictory real rights were downgraded to personal status unless rightholders opposed the intended transaction either during the ceremony or within the prescription period. Second, mancipatio provided the basis for future legal procedures, as the law granted substantial procedural advantages to possessors against other claimants. It is analyzed more deeply in Arruñada (forthcoming), with special attention being paid to the purging role of witnesses. 
require publicity when transferring them. ${ }^{11}$ This ceremony produced a public conveyance which was separate from the private contract, setting the two-step contracting process characteristic of property and already present in many primitive legal systems (Arruñada 2003). It therefore had a titling function in that it publicized the conveyance and served to gather the consents of affected rightholders. In doing so, it allowed conflicting claims to be purged either at once or after a certain period.

These ceremonial conveyances become less efficient when markets expand (Arruñada 2012:53-54). Celebrating them is more costly when parties travel more and reside in different places. Moreover, they are more effective in local markets, where transactions take place between neighbors, as is common in rural societies. Indeed, for neighbors, it is easy to notice announcements and public deals, especially for the kinds of rights common in rural societies, many of which are linked to family matters. Conversely, it is harder for non-neighbors, as confirmed by the longer prescription periods granted to those absent, apparently balancing costlier knowledge with longer time.

Roman law adapted to the demands of wider markets by developing a highly sophisticated doctrine of legal (as opposed to merely factual) possession that could be used more effectively as a titling device. In principle, to the extent that the exercise of possession has observable consequences, it can provide the basis for titling, by upgrading it to ownership over time - by acquisitive prescription or "usucapion". ${ }^{12}$ In Rome, initially, undisturbed possession of land and other capital assets for only two years (one year for other movables) led to ownership by usucapion if acquisition was in good faith and was based on proper cause, even if conveyed by mere delivery of possession without public ceremonies. Furthermore, as early as the late Republic, judge-made law in the form of Praetorian edicts - a type of jurisprudence based on the judicial choice of remedies (Nicholas 1962:19-27) — enhanced the protection enjoyed by the good faith possessor on the way to usucapion by granting him an action that ensured he succeeded even against the formal owner (if the possessor's title was defective, having been delivered informally) or against everyone but the owner (if the title was substantively defective because, e.g., he had bought from a non-owner). As a consequence, the buyer who had been delivered the asset "was for nearly all practical purposes in the position of an owner" (Nicholas 1962:127).

In this context, it is important to realize that the key element for usucapion to work effectively as a titling procedure is that the exercise of possession should provide claimants with the information they need to litigate and protect any property rights infringed by the intended transaction (e.g., Rose 1985:78-81). It therefore implicitly provides the basis for starting a selective purge of adverse claims, and all that acquirers need to check only is that the seller has effectively been in possession for the prescription period.

11 Views considering that the doctrinal separation between real and personal rights was driven by the legal requirement reverse the direction of causation. The inclusion of some types of movables in res mancipi should not be seen as a "useless but ubiquitous complication" (Crook 1967:141), because such movables were high-value capital goods suitable for multiple rights to be held on them. A similarly naïve view considers Roman conveyance requirements as formalistic (e.g., Riggsby 2010:137), forgetting that formality contributes to the publicity necessary for efficiently enforcing real rights.

12 For a more extensive treatment of the titling role of possession, see Arruñada (2015). 
The information provided by possession is open to question, especially if the delivery of possession was made without any visible transfer of the asset, as was increasingly the case, ${ }^{13}$ and this, together with the decreasing use and limited efficacy of the mancipatio ceremony in a vast economy, ${ }^{14}$ has led some authors to think that Roman publicity was ineffective (e.g., Nicholas 1962:104). However, this critique is unwarranted because, for existing rights to be protected under usucapion, possession only needs to inform affected rightholders with sufficient time for them to take action. And owners can always make their possession public if, foreseeing a possible sale, they want to convince future acquirers that they will be protected by the seller's usucapion.

Consistent with this titling view of possession is the fact that in Rome the time required for usucapion was longer when the information provided by publicity also took longer to process. Standard usucapion was part of the civil law and therefore applied only to Roman ownership: i.e., Italic land held by Roman citizens. For provincial land, longer prescription periods were required (Nicholas 1962:128), which makes sense because of the greater distance and time needed by adverse claimants to get notice. The time for usucapion also became longer in the last centuries of the Empire, consistent with greater civil unrest and consequently greater information and purging difficulties. ${ }^{15}$

Furthermore, it must be kept in mind that in Rome possession was narrowly understood to mean "not simply the holding of a thing but rather the holding of a thing in the manner of an owner, the exclusive holding of a thing" (Nicholas 1962:111). Those holding without possessing were physically occupying the land but lacked relation to it. This allowed Roman law the simple expedient of not enforcing certain rights in real terms, mainly those of lessees, who did not have possession. Under the rule "sale breaks hire," lessees were thus less protected, because, when a lessor-owner violated an agreement with a lessee and sold the asset, the lessee would have to relinquish the asset to the buyer and would only hold a personal claim against the lessor. However, buyers also suffered less information asymmetry, as they could be sure of buying without the burden of leases.

The sophisticated use of possession and usucapion therefore provided an effective palliative for transfers of ownership, and several controversial issues are illuminated by this titling role of possession. For a start, analyses that consider that granting ownership by prescription based on possession and the lapse of time "makes possible the proof of ownership by depriving it of its ordinary meaning" (Nicholas 1962:156) disregard that the public nature of possession allows claimants to vindicate ownership during the prescription period. It therefore implicitly provides

13 I have discussed elsewhere (Arruñada, forthcoming) the seemingly later evolution towards private conveyancing through delivery of the asset or even, in the late Empire, by merely granting a written deed.

14 It is likely that the mancipatio term appearing in later Roman documents really means only conveyance (Nicholas 1962:117). Meyer argues that formal conservatism (syntax, style, rhythmic prose) in Roman documents conveyed authority (Meyer 2004:59). Her argument might help explain why the word mancipatio was still used even when the title was transferred by granting a written deed.

15 At the time of Justinian, while only three years were required for usucapion of movables, longi temporis praescriptio became the only usucapion for land, requiring a minimum of 10 years for land if parties were in the same district or 20 years if they were not. A longissimi temporis praescriptio of 30 years was also enacted for good faith acquisitions of movables that had been stolen (Nicholas 1962:128). 
the basis for a judicial purge of ownership claims: ownership does not exist as a titling- (i.e., judicially-) independent reality. Similarly, seeing possession as a main element of the titling process denies claims that the importance Roman law attached to possession rather than ownership "indicates that Roman law was seriously concerned with preservation of the status quo and keeping the peace, and less so with questions of formal entitlement" (Johnston 1999:60). Possession was a tool to ascertain which claimant would be the owner. Ownership claims should not be confused with ownership rights. Lastly, when considering the role of possession in the titling process, views of a two-part land tenure system in Roman land law (e.g., Temin 2013:147) also seem unwarranted. From a titling perspective, this duality makes sense not as a two-part tenure system for different land but as a two-step titling process for the same land: possession was simply the publicizing element in the second step within the titling process ending with usucapion. Possession was the path to ownership, not its alternative.

However, the limitations of possession as a titling palliative are also visible in the inability of Roman law to implement efficient real securities, which is understandable due to their abstract nature and the consequent difficulties to make them publicly known by such palliative means. To provide lenders with an effective real security, a sort of mortgage was instrumented on the basis of selling the property to the creditor with an agreement that it should be returned to the debtor if he paid off the debt. ${ }^{16}$ This therefore reduced the default risk for the creditor but created a dispossession risk for the debtor (who held only a personal action against the creditor if the creditor breached the agreement not to sell), which helps explain why they most often resorted to personal sureties. ${ }^{17}$ Alternatively, Romans could, of course, easily add real securities to their personal obligations and sureties, but the effectiveness of such real securities would have been doubtful. ${ }^{18}$ The situation may have been comparable to what is common today in countries

16 By this mancipatio cum fiducia, similar to the late medieval English mortgage (Nicholas 1962:151), the owner gave ownership to the creditor and authorized him to sell if the debt was not paid, allocating the possible surplus to the debtor (e.g., Crook 1967:244-45). There is also evidence in the Digest that at some point real securities might have been reinforced, as in old Mesopotamia and modern England (Arruñada 2012:46-47), by pledging the deed or the whole chain of deeds with the creditor (Scaevola D. 13.7.43). This pledging of deeds also subjects the debtor to the creditor's moral hazard, as he may fail to produce the deed when the debtor needs it or may even fraudulently sell, and also makes it harder to subrogate the debt and contract second mortgages. The Digest case makes this point clear, as the creditor fails to produce the deed to the debtor, who is therefore unable to prove the extent of his land and cannot fully develop it.

17 Personal surety was very common for any substantial transaction on credit (Nicholas 1962:151). It has even been argued that Romans preferred personal rather than real securities because of status: "a wealthy Roman's word was his bond, and security as potent as any pledge" (Johnston 1999:88). Posting a real security might even have been detrimental to personal reputation, as it might signal that the debtor's word was not valued by potential creditors and, worse still, that he had no friends willing to back him. From this perspective, reluctance to accept publicity would have been limited to the posting of real securities, not to mere indebtedness; and such reluctance would be hard to reconcile with the above-mentioned prevalence of circular credit networks among friends.

18 Securities were indeed easy to create by the will of the parties, as argued by Verhagen (forthcoming, $p$. 9). However, ease of creation is, at most, a partial and doubtful advantage. Partial, because such ease ex ante comes at the price of, first, greater information asymmetry at the time of contracting (given the possibility of hidden real charges, creditors know less than debtors about the value of the security); and, 
lacking effective land registries: parties add real securities to their contracts but this hardly reduces default risk or, consequently, the interest rate, because of uncertainties regarding possible prior liens granted by the owner-debtor (Arruñada 2012:43). In other words: due to the possibility of hidden charges, the enforcement of such real securities was in fact most likely based on the personal sureties offered by the debtor and his guarantors, not on the collateral value of the debtor's land. Therefore, the presence and sophistication of real securities in surviving contracts, or their treatment in legal texts tell us little about their economic relevance. ${ }^{19}$ Similarly, and whatever their effectiveness, imposing criminal sanctions on those who hid such charges can also be seen as a sign that secrecy and fraud were hindering these transactions.

Given these limitations, it may come as a surprise that land registration "was quite unknown to Roman law" (Nicholas 1962:104), especially considering that Rome revitalized the land registers of Egypt (Lerouxel 2012a:648-51) and built extensive cadastres and civil registries, as explained below. The most likely reason lies in the relative inefficiency of land registries compared to that of the palliative solutions analyzed in this section. ${ }^{20}$ In addition to some other considerations, ${ }^{21}$ two main factors must be kept in mind. First, to be functional, land registries must produce reliable judicial evidence for situations which, given the involvement of at least three interested parties, are more prone to conflict than those arising with either cadastres or civil registries. Cadastres only have direct effects on the taxpayer (Arruñada 2012:205) and, even if civil registries may have effects on third parties, these effects usually take place years after the filing, which reduces moral hazard. This means that land registers are more costly to maintain and more prone to breakdown, as made clear by the high operating cost (Lerouxel 2012a:652)

second, ineffectiveness of the guarantees ex post (if a prior hidden charge appears or a title risk materializes) and costly enforcement to clear title before repossession (even if hidden charges do not surface). It is also a doubtful advantage when considering that total transaction costs may well be lower when the law reduces the variety of real rights by means of a numerus clausus of such rights (Heller 1999, Merrill and Smith 2000, and Hansmann and Kraakman 2002).

19 Verhagen (forthcoming:1-2) bases his positive assessment of Roman real securities on two facts: that the Sulpicii bankers used real securities for large loans, and that real securities were extensively discussed by jurists, as well as in the Digest and the Codex. However, on the one hand, the Sulpicii relied on pignus - transferring possession to the creditor-, a primitive form of real security. And, on the other hand, extensive legal treatment of a given topic may well be an indication of conflict rather than low transaction costs, as shown, for instance, by the examples taken from the Digest by Verhagen (forthcoming:21).

${ }^{20}$ In a more exhaustive analysis, a broader set of possible explanations should be considered. Even if registries were efficient in the Roman context, the Roman state might have been prevented from adopting them by some rigidity or failure, such as path dependency or the prevalence of private interests. However, both possibilities seem less likely when considering that the story unfolds over several centuries.

${ }^{21}$ I analyze the issue in greater detail in section 4 of Arrunada (forthcoming), examining the evidence on archives and registries. The literature contains many references to Roman land registries, often confusing them with administrative records of land distribution and land cadastres, which have a taxing purpose so are much easier to organize. The confusion between cadastres and registries is a version of a wider confusion in historiography between administrative (mainly tax) and contractual or "economic" archives (Sánchez-Moreno 2013:660). The necessarily public element in real rights adds to the confusion by incorporating this public element to what are functionally private contractual registries (Arruñada 2012:59-60). 
and organizational difficulties experienced by land registries in Roman Egypt. ${ }^{22}$ In fact, it is only recently that a few countries in the world have been operating effective land and company registries, ${ }^{23}$ although with sporadic breakdowns, as shown by the current foreclosure crisis in the USA (Levitin 2013). Second, creating and managing registries require a degree of centralization and continuity that might have been unsuitable for the Roman judiciary, given its formulary procedure and its annually appointed magistrates and nonprofessional judges chosen by the parties. Similarly, switching adjudication rules (from considering that legal effects start at the date of public filing instead of at the date of private contracting) or even granting privileged status to registry evidence would not tie in easily with the evolutionary character of Roman law, which developed new legal doctrines such as the ones on agency by simply adding new remedies to the old ones. ${ }^{24}$ In sum, doubt as to land registries' efficiency and fitness may help explain why the Romans, while prepared to accommodate local legal systems and upgrade the registries that provincial governors found in Eastern provinces (mainly the Egyptian "registry of acquisitions" or bibliotheke enkteseon), ${ }^{25}$ seemingly made no attempt to introduce land registries in the West. ${ }^{26}$

22 These difficulties included many aspects that are familiar to modern registries, such as the enforcement of unregistered public charges, the reluctance of acquirers to register (probably triggered, as usual, by the State giving in to the temptation of using registration for tax enforcement); as well as resistance to serve as a keeper of the register (Monson 2012:127-31). The register seems to have been subject to repeated reform efforts, such as those enacted in 89 C.E. (Lerouxel 2012a:656-57). However, it is significant of the market-supporting role of the Roman administration that at some point it considered the marketdebasing effect of strictly enforcing tax duties as tacit real charges and renounced this privilege (Lerouxel 2012a:656-57), something that even contemporary states rarely do. Of course, this emphasis on enabling the market was not permanent. In later centuries, the state simply gave privileged status to the treasury (Nicholas 1962:153; Crook 1967:246) without paying attention to the increase in transaction costs caused by these tacit charges, especially in the absence of effective registries.

${ }^{23}$ Although many petitions had been made by cities since the low Middle Ages, most European rulers failed in creating land and company registries. They only started to succeed in the $19^{\text {th }}$ century, and ineffective registries are still the norm in most of the world (Arruñada 2003).

${ }^{24}$ Even professional judges have often been reluctant, in diverse historical circumstances, to grant conclusive effects to evidence produced by property registries (Arruñada 2012:241, n. 39). See, for instance, Rose (1988) for the case of the American colonies.

25 Roman law was generally flexible to local conditions, upgrading local institutions, retaining local law, and subjecting different subjects to different sets of law (mainly, for citizens and non citizens). After the First Punic War (264-241 B.C.E.), the state responded to the increase in foreign population in Rome by creating a specialized magistracy for dealing with non-Roman citizens with a focus on conflicts related to interregional trade. This Praetor peregrinus applied the law common to all nations or ius gentium (Nicholas 1962:7, Winkel 2013:3553).

${ }^{26}$ Even efforts to make hypothecs public in the West came quite late: not until 472 C.E. was priority granted to hypothecs created before a public authority or before three witnesses (Nicholas 1962:153), therefore with an element of publicity. 


\section{Impersonal exchange in business}

The scope of business transactions and therefore the extent of markets and specialization also expand greatly when market participants can trade impersonally, without any need to know their trading partners. In particular, the possibility of using agents capable of legally committing their principals provides substantial specialization advantages, extending the scope and coverage of business operations: by separating ownership and control of assets, it allows owners and agents to specialize in many dimensions; by reassuring buyers on their purchases, it encourages them to buy from more selling agents. This explains why in many situations the strict enforcement of property rights is superseded by rules granting innocent buyers (acquirers, in general) priority access to the principals' assets - i.e., making the principal (the owner) liable for his agent's contractual obligations. However, efficiently solving the resulting conflict between the security of owners' property and the reduction of transaction costs is not an easy task, and requires sophisticated institutions.

The key element is for judges to verify owners' authorization of agents, granting owners freedom as to how to authorize agents but also ensuring that owners remain committed to their choices. Owners must be effectively committed so that they cannot behave opportunistically, by reneging on their authorization when the agents' interaction with buyers turns out badly for the owners' interests. In recurrent business operations, legal systems may use for judicial verification the consequences of transactions which, being publicly observable, are hard to manipulate. This is the solution developed within the Medieval Merchant law for the rules protecting good faith purchasers (Berman 1983:348-50). According to these rules, when, e.g., a buyer purchases from a merchant who was given possession by a merchant-owner, she will not be disturbed in her ownership even if the seller cheats on the previous owner. The property right of this owner therefore becomes a mere personal right once he delivers the asset to his agent. Institutional innovation of this type is often harder that it seems, however, because the new rules depart starkly from previously established rules, which are adapted to personal exchange. The difficulty is illustrated by the fact that the modern rules protecting good faith purchasers were developed by courts staffed by merchants, not by lawyers, likely because of the opposition of entrenched professional interests. ${ }^{27}$

\subsection{The adoption of agency principles in Roman law}

In Rome, the starting point for this type of innovation could hardly have been worse, as early Roman law lacked a proper law of agency. In fact, "the strictly personal character of the Roman obligation ... made agency impossible [in the sense of creating a direct relationship between principal and third party, and the agent] alone was both liable and entitled on any contract which

${ }^{27}$ For instance, such protection of third parties was introduced in the Merchant law in the $12^{\text {th }}$ century (Berman 1983:348-50) but in the areas of representation and agency it struggled to get accepted into both the civil and the common law until the $17^{\text {th }}$ century or even later (Zimmermann 1996:41-58). 
he made" (Nicholas 1962:189). Contracts therefore could only impose obligations on those entering into them, and not on third parties. ${ }^{28}$

This strict enforcement of property rights made no sense after trade opportunities substantially increased in the second century B.C.E. ${ }^{29}$ Consistent with this trade-expansion hypothesis, Praetorian edicts came again to the rescue and diluted such strictness by making principals liable and therefore protecting innocent third parties. The key innovation was to enhance the role of slaves and sons as economic agents, ${ }^{30}$ in two opposite directions: on the one hand, making masters and fathers liable for the acts of their slaves and sons; and, on the other, by limiting the masters' and fathers' liability to the assets assigned to the sons or slaves.

These changes were close to modern solutions in their function and their operation, as both were based on appearance and publicity.

First, the principal was made liable when it was clear he had authorized the agent, a solution fully respectful of private property rights, as it is the owner who chooses when and how he is interested in authorizing agents. Since the second century B.C.E., judge-made Praetorian law made the household head or paterfamilias liable for obligations entered into by his sons or slaves, with his liability increasing with the authority he had granted or with his involvement in any businesses run by his sons and slaves. ${ }^{31}$ In particular, he was liable in full when he had authorized the agent explicitly, implicitly, or by allowing similar dealings: not only when the master ordered the transaction but also when he put the agent in charge of a business or a ship. In such cases, the scope of liability was limited to contracts made in connection to the business, and

28 What in English law is called the "privity" of contract was rigidly applied (Nicholas 1962:199). Initially, the only exception were rights acquired by slaves and sons, which vested in the household head (Nicholas 1962:199). This asymmetry in the rule (with principals not being liable but able to acquire rights through their sons' and slaves' actions) made sense because the third parties granting a right to the slave owner were themselves owners; therefore, they had ultimate control of the situation and could take good care of their interests. With little potential for conflict, this solution must have facilitated some degree of exchange and specialization, as slave owners needed to be present to commit themselves on any obligation but did not need to be present to acquire rights. Indeed, we find similar asymmetries in today's economy: banks are often allowed to modify the land registry, but only against their own interest (e.g., by filing a mortgage cancellation).

29 According, e.g., to archeological evidence on the number of shipwrecks (Parker 1992).

${ }^{30}$ Romans also made ample use of the mandate (mandatum), which they understood as a contract by which a person (mandatarius) agreed to perform for another (mandator), usually a social equal, and at his request, an unpaid service, which commonly consisted of entering into a contract with a third party (Nicholas 1962:187). However, from the perspective of impersonal exchange, this solution suffered two main limitations that likely kept it in the sphere of personal relations, mostly of a reciprocal type and taking place among friends: the mandatarius was not paid and his actions did not commit the mandator. For an economic analysis, see Kehoe (forthcoming).

31 This was achieved by introducing several remedies later referred to as actiones adiecticiae qualitatis, a name emphasizing that they did not transfer the liability to the master but simply created an additional liability corresponding to the master's appropriation of benefits derived from the slave's activities (Nicholas 1962:202-203). These remedies provided a nuanced gradation of rights and liabilities for the principal, as analyzed by Aubert (1994:46-70), Wacke (1994) and Abatino et al. (2011). 
could be narrowed by giving proper notice (Crook 1967:190, Johnston 1999:103). ${ }^{32}$ Moreover, similar principles were extended outside the family when a freeman was appointed as a manager or institor (Nicholas 1962:203-204). And at least one of these judicial remedies (the actio institoria) made it possible to commit the principal on the basis of appearance (Petrucci 2003), so that apparent authority therefore played a role similar to that played by possession in the area of property. The principal was protected only by an explicit prohibition, and the rules seem to have evolved in such a way that the master was liable. Thus, third parties were protected when the agent exceeded his powers through actions not explicitly forbidden and made adequately public by the master. ${ }^{33}$ Roman law was therefore considering the same basic elements of consent and publicity that we find today in business agency (Arruñada 2010).

Second, the principal could also limit his liability to the part of his wealth managed by the agent (the peculium), therefore enjoying some degree of "asset partitioning." 34 The peculium was a separable set of resources which, even if by law it pertained to the master, was controlled by the slave or the son, ${ }^{35}$ and was first in line in terms of satisfying the contractual commitments made by the slave or the son to third parties. Asset partitioning was achieved through a complex set of legal actions that arguably resembled contemporary remedies for tackling standard conflicts of interests between shareholders and company creditors, such as abnormal distribution of dividends and self-dealing (Djankov et al. 2008), or the "tunneling" of corporate resources to insiders (Johnson et al. 2000). Avoiding self-dealing could be behind the rule that, according to Gaius (170:IV.72), constrained the discretion of the master to pay himself to the detriment of the slave's creditors. Avoiding appropriation by insiders may also have inspired the rule making the master liable for payments made to him from the peculium (Gaius 170:IV.73). In general, the rules seemingly tried to link the liability of the principal to the benefit he was obtaining from the business (Crook 1967:189). This normative linkage to benefits seems appropriate for avoiding the main risk faced by innocent third parties in the absence of proper institutions: the attempt by principals to renege ex post on their own ex ante commitments once the business entered into by their agent goes against their interests.

32 "The area of competence of the agent was defined in a charter (lex praepositionis) or by custom or common sense; it could be restricted by posting at the workplace a written sign (proscriptio) in any language, or extended to specific activities by a special invitation (iussus/-um) addressed by the principal to third contracting parties" (Aubert 2013:3466).

33 See Petrucci (2003:607-10), discussing D. 14.5.8 Paul. 1 decret.

34 See Hansmann and Kraakman (2000), and Hansmann et al. (2006). Having a slave operating a business provided masters with the possibility of delegating the management of business activities and benefiting from direct agency, limited the master's liability, provided some "entity shielding" against the master's creditors, and helped to ensure the continuity of business after changes in ownership and management. See Abatino et al. (2011), who even find traces of entity shielding between different businesses belonging to the same owner.

35 While the slaves' peculium may have been more important economically, "it is overwhelmingly probable that married sons living independently had such a fund" (Crook 1967:110). 


\subsection{Remaining questions on Roman agency}

Despite these developments, the Roman law of business agency still poses many puzzles. A major question is why sons and slaves played such a prominent role as contractual agents, which suggests that they enjoyed a comparative advantage over individuals who were not under the power of a household head as they themselves were. This advantage seems to have lasted at least until the early third century (Johnston 1999:106) and is supported by the occasional practice of freeborn individuals becoming slaves to act as chief manager or accountant of a big household (Crook 1967:60, Ramin and Veyne 1981).

It has often been argued that the advantage was linked to failures in formal law; in particular, to the incompleteness of agency-independent labor (Nicholas 1962:203, Johnston 1999:105106). However, it seems unlikely that such failures would have remained uncorrected for long considering the adaptability shown by judge-made Praetorian law. Alternatively, this comparative advantage may have been rooted in lower transaction costs in either their originative and/or their subsequent contracts: that is, in better incentives for agents and/or less information asymmetry for third parties. First, the incentives provided by family and slave law directly lowered agency costs in originative contracts, not only by making harsher punishments available, which may be suitable in conditions of information asymmetry (Dari-Mattiacci 2013), but also because of judicial restraint, as I will argue in the next section. Second, using sons and slaves as contractual agents also reduced information asymmetry in subsequent contracts for two reasons: It was easier for third parties to identify them as contractual agents, and their status was not easy to modify ex post, so principals were prevented from freeing themselves from any undesired commitments. As argued in the next section, this explains the structure of family membership formalities. It is true that the advantage seems more nuanced for subsequent transactions with third parties, who may have been reluctant to contract with sons and slaves because in some circumstances they would have had access only to their peculium, so recovery would have been harder (e.g., Gaius 170:IV.74). However, for the same reason, such contracting was safer for the household head, suggesting the presence of a tradeoff. Most importantly, it was possible for the household head to optimize this tradeoff in accordance with the specific circumstances of the business, by modifying his public involvement and, consequently, his liability.

There also seems to be substantial discrepancy on the prevalence of corporate entities in the Roman Empire. On the one hand, through a contract of partnership called societas (e.g., Riggsby 2010:13), someone selling to the partnership was selling to the individual partner with whom he was dealing with. If he was not paid, he had no recourse against other partners. In general, "legal personality was not available for private businesses" (Abatino et al. 2011:368). On the other hand, big tax farming companies enjoyed special rules: e.g., death of a partner or litigation between partners did not dissolve the company (Crook 1967:234). It has even been claimed that there were proper companies, at least for tax farming and shipping, and that they were functionally similar to the European joint-stock companies of the sixteenth and seventeenth centuries, with their own legal identity and continuity after the death of their investors, with separation of ownership and control and with shares being traded at variable prices (Malmendier 2009). ${ }^{36}$ However, substantial doubts remain about such companies concerning their use of

36 The existence of corporate entities in shipping, alleged by, e.g., Malmendier (2009:1089) and Temin (2013:103) on the basis of a statement attributed to Cato by Plutarch seems to be grounded on a weak, 
shares and their legal personality (e.g., Crook 1967:234-35). Moreover, they seem to have been an exception, not only in their structure but also in terms of time, being dated mostly in the first century B.C.E.

Given that partnerships for tax collection and building projects were governed by special rules that included incorporation and entity shielding, the legal and judicial expertise for contracting them must have been available to the Romans: that is, the basic "technology" for corporate contracting had already been developed. However, corporate contracting is exceedingly costly when, in the absence of company registries, it is based purely on the informal publicity that emerges from daily business operations (Arruñada 2010:556-58), as shown by the experience of English unincorporated companies during the Industrial Revolution (Harris 2000). The fact that Roman tax farming companies were chartered by the state indicates that, even if the company solution was available to the Romans, it may have been ineffective when used without some form of public chartering. The historical record is therefore consistent with the interpretation that, as in the modern English case and given the lack of company registries, large corporations were viable when based on the public chartering process leading to the concession grant but were hardly viable on a purely contractual basis. ${ }^{37}$

However, in contrast with the English case, in which we observe decades-long unsatisfied demand for proper incorporation, leading to the contractual solutions analyzed by Harris (2000), there are no indications of such unsatisfied demand in Roman times. The basic reason why corporations were not used for other activities and industries might be that for such activities there was simply little need to use them. There was probably not enough demand for more stable business associations: available technology did not require the large amounts of capital and continuity that, for instance, infrastructure projects and railroads were to require at the time of the Industrial Revolution. ${ }^{38}$ In Rome, few business opportunities required the corporate form of business organization. Therefore, only a few large companies incorporated, relying on the publicity provided by the public calls and auctions linked to tax farming and government subcontracting.

temporary, basis (Verboven 2002:285), even if shipping is an activity that allegedly poses relatively discontinuous and therefore simpler contractual problems. Moreover, Plutarch wrote almost 200 years later and might have been prone to exaggeration (see, for another likely example, Ellickson, forthcoming).

37 Compare Malmendier (2009), who omits any consideration of the difficulties faced by companies created on a purely contractual basis and emphasizes political considerations in the demise of the large societas publicanorum in the Roman Empire. They ultimately disappeared because the state changed the way it collected taxes and produced public services, moving away from pure tax farming towards more sophisticated forms of subcontracting, with greater control of subcontractors, sharing of revenues and development of the state's bureaucracy (Gibbs 2013). It is not clear that these changes in public finance worsened the environment for the market economy, which in fact flourished during at least a couple of centuries after them. Moreover, modern evolution away from tax farming (see, for instance, Johnson and Koyama 2014) could be understood as supporting the superiority of direct collection. In any case, whatever the merits of tax farming, the most pressing question for us is why the corporate form used by tax farming did not prosper in other activities and, in particular, why this form was not used for organizing other private economic activities either before or after such changes in fiscal policy.

38 Compare to the firm size constraint argument in Abatino and Dari-Mattiacci (forthcoming). 


\section{Institutional enhancement and adaptation of personal exchange}

Economic agents must often choose between transacting personally or impersonally. When impersonal exchange is impossible, transactions either rely on personal safeguards or are not made at all and become lost opportunities. In particular, the harder it is to enforce rights in real terms, the more they will be enforced in personal terms. For example, when real securities for credit are weak, the total amount of credit will be smaller, existing credit will tend to be more personal, and transactors will rely more on personal sureties.

Similarly, within legal systems, there is substitution between institutional support for personal and for impersonal exchange. Also, informal norms and formal rules might be adapted to facilitate such substitution. If a society relies more on personal exchange, one can expect individual reputation to play a greater role and personal sanctions to be harsher. ${ }^{39}$ This was seemingly the case in Classical Rome, where, at least initially, informal social norms strongly motivated people to fulfill their personal obligations. What is most important for understanding the role played by the Roman state is that both formal rules and organizationally supported institutions were well suited, and seem to have evolved, not only to enhance the enforcement of personal obligations but also to prevent them from interfering with impersonal exchange.

\subsection{The role of informal norms and formal rules}

Roman society placed great importance on personal honor and reputation, which was the basis for strong horizontal and vertical bonds that provided safeguards for all sorts of exchanges. As a consequence, fulfilling contractual obligations was a matter of personal honor (Temin 2013:12). Horizontal bonds meant that substantial mutual help was customarily provided by people equal in status, mainly under the informal bond and obligation of friendship. "Friendship (amicitia) gave rise to serious and substantial duties. Roman friends made claims on each other which would cause a modern 'friend' to break off the relationship without delay" (Schulz 1951:555). And vertical bonds amounted to several layers of patronage by people of higher status, who acted as patrons for their lower-status "clients," the clientela. In the early Republic, the situation was close to serfdom, but survived later mainly for the relation between patron and freedman (Crook 1967:93). Also, in the more specialized area of commerce, informal personal ties were important among Roman merchants for gathering information relevant for contractual enforcement. Traders often belonged to the same social groups (Temin 2006:139), were able to exchange information (Kessler and Temin 2007) and, to reduce information asymmetries, relied not only on personal ties, family members and peer monitoring but also on formal guilds and some state institutions (Temin 2013:100).

39 See Arruñada (2012:50-52). A more formal discussion of the choice faced by the Romans with respect to institutional support for impersonal exchange is also given in the second section of Arruñada (forthcoming). 
These personal bonds were based on individuals' informal reputation but were also supported by formal mechanisms. First, losing reputation was subject to informal sanctions, but these soon acquired a formal version in judicially imposed exclusion from the legal protections enjoyed by Roman citizens. ${ }^{40}$ Second, reputation itself was also formally protected: defaming another person was harshly punished. Third, the role of reputation was reinforced with the census, which was not a mere list of persons but established a formal classification of individuals defining their rights and duties and including a negative mark for those who offended public morality. It thus amounted to a formal register of reputation. Lastly, the formal legal system also relied on and reinforced the informal system of social norms to the extent that the value that Roman judges placed on evidence depended to some extent on the social standing of those providing or witnessing it (Meyer 2004).

However, there are multiple signs that informal personal bonds became less effective over time, as indicated by Seneca's famous complaint in the first century C.E. that faith (fides) was no longer enough and debt now needed to be formalized by means of written and sealed documents, with the seal giving increased physical protection (Meyer 2004:156). This dilution of personal bonds is consistent with more extensive markets and a growing share of impersonal exchange. In particular, greater opportunities for impersonal exchange, made viable by economic growth and institutional innovation, also made preexisting personal safeguards (such as reputation and networks of clients and friends) less effective and less valuable, and discouraged economic agents from investing in them. From this perspective, Seneca's complaint would be likely to be reflecting the loss of privileged contracting possibilities that the Roman elites were suffering when impersonal exchange was becoming more viable and prevalent.

Moreover, informal social norms were enhanced by an array of formal rules that not only ensured enforcement of personal obligations but were selectively reinforced or diluted for common situations in which such reinforcement or dilution respectively supported or collided with impersonal exchange. Norms were reinforced when adjusting monetary penalties and criminal sanctions to informational advantages. In particular, an early legal rule imposed on sellers a penalty of twofold the price when the buyer lost the property due to a defect in the seller's title, ${ }^{41}$ which must have motivated sellers not only to disclose but also to discover and purge possible title problems. With somehow similar effects, since the end of the second century C.E., it was made a crime to mislead a creditor about prior charges (Johnston 1999:93).

In addition, formal rules also evolved over time to dilute the enforcement of personal obligations that might collide with impersonal exchange. This is most visible in the nuanced regulation of self-help (i.e., personal enforcement). Self-help was always important for contract enforcement, but Roman law somehow struggled with it (Bürge 1980) and reduced its scope over time, thus adapting it to increasingly impersonal exchange and, in particular, to the greater presence of third parties whose interests would have been damaged by unrestrained self-help.

40 Those of ignominia and infamia (Crook 1967:83-85).

41 This remedy, known as actio auctoritatis, protected buyers of res mancipi (Nicholas 1962:161, n. 1), but a similar solution, known as stipulatio duplae, was often established by mutual agreement for other types of goods or transactions (Kaser 1971:553-56). It appears that vendors' banks were also liable for eviction guarantees, at least in the case of slaves (Temin 2013:182). This would constitute a precedent of modern property "title insurance". 
Thus, self-help initially consisted of execution of the wrongdoer by the creditor, including victims of crimes, who were entitled to a payment from the wrongdoer. Later, however, even if creditors could still privately imprison defaulting debtors, they remained liable with respect to other creditors (Nicholas 1962:209-10), who would play the role of third parties in my framework. Similarly, judicial enforcement was also based on personal execution: the plaintiff was authorized to imprison the debtor and sell his whole property. But this was only possible after an additional "action on the judgment" (Crook 1967:82-83), whereby the seizure was publicized and the seized property had to be administered on behalf of all the creditors (Johnston 1999:108-10). In the Republic, the law also restricted debt bondage. For instance, after 326 B.C.E., a debtor could not pledge himself or a son, as collateral for a loan, to become the creditor's slave in case of default. More than for humanitarian reasons, this constraint was likely driven by a desire to protect all creditors equally, a possibility supported by the fact that debt bondage could still result from the debtor's default (Crook 1967:173). Along the same lines, the law made it possible to undo transactions taking place within the year preceding insolvency if they benefitted a creditor to the expense of other creditors (Johnston 1999:109). Lastly, at least after the reign of Marcus Aurelius in the second century C.E., the imperial government also placed the enforcement of mortgages under the authority of the courts (Kehoe 2013a:45-46), probably to avoid damage to third parties holding rights on the same land. This also enhanced the enforcement of real rights and, therefore, impersonal exchange.

All these legal changes therefore diluted personal enforcement when it would have endangered impersonal exchange. They indicate that the Roman state adapted its institutions to support impersonal markets. The next section shows that a similar adaptation took place at a more general level, because social norms protecting personal exchange were also adapted to impersonal exchange by two sets of arrangements enabling the extended family to act as a contractual entity. First, by allocating most decision rights to the household head. Second, by neatly defining the family's boundaries and, therefore, establishing who could act as its contractual agent, committing the family's assets to meeting its obligations.

\subsection{The role of judicial forbearance in enabling self-enforcement}

Concentration of property and decision rights on the Roman household head, including those on slaves and sons, defined an ambit in which judges would not enter - an ambit of judicial restraint or "forbearance," using the term coined by Williamson (1991). ${ }^{42}$ This refusal of judges to enter into intra-family disputes allowed an asymmetric allocation to the household head of property rights on other family members. ${ }^{43}$ Therefore, families were able to fully rely on selfenforcement in their internal transactions and to act as quasi-firms with respect to third parties.

\footnotetext{
42 About agency, it is said that "these were relations that never reached the inside of a courtroom. Their entire tone precludes contract and suit, action and liability; yet they were most effective in fulfilling the roles and needs lawyers associate with agency" (Kirschenbaum 1987:180, cited by Temin 2013:111). Indeed, they precluded contract and suit, but only inside the family, in a similar fashion to modern firms.

43 Asymmetric allocation of decision rights with judicial forbearance plays an important role in today's economy (e.g., for franchising, Arruñada, Garicano, and Vázquez 2001), even if these private-ordering
} 
Several factors enhanced this system of self-enforcement. To begin with, it encompassed not only the family sensu stricto but also the wider family's clientela: "it would have been impious and unlawful for patrons and clients to litigate or testify against each other or to support each other's enemies" (Verboven 2013). Second, judicial forbearance was enhanced by the paucity of mandatory rules about key aspects of family law, including, most prominently, substantial freedom of testation (e.g., Crook 1967:118-27), which brought stronger incentives for sons and other possible heirs, including slaves. Third, this concentration of rights in the household head had consequences both inside and outside the family. Inside, it facilitated enforcement. Outside, it helped achieve some of the "modularity" provided today by business firms (Smith 2006 and 2009). For instance, reputation was linked not only to individuals but to the whole family, alleviating possible horizon problems. Lastly, it makes sense that Roman law carefully protected the family against possible mistakes when the young age of the household head could lead him to exercise these decision rights poorly. It did so not only with the institution of guardianship, applied to children younger than 14 and women, but also with a "caretakership," which was common for minors aged between 14 and 25. The rationale behind both tutorship institutions was probably to avoid the difficulties that families would otherwise have faced for contracting, given that, in the absence of such institutions, transactions could have easily been nullified later on by alleging fraud (Crook 1967:113-18).44

\subsection{The role of formalities with respect to family membership}

The importance of the family as a contractual entity and the need to make impersonal exchange viable also explain the sophisticated formalities and cautions used by Roman law to define family boundaries. As a consequence, all family entries and exits were subject to formalities and, therefore, to publicity: not only marriage, which, even if form-free (Nicholas 1962:80-81), required a clearly manifested intention, customarily evidenced by two-step

arrangements are constantly under the threat of legislative and judicial intervention, as illustrated by the evolution of franchise law (Brickley, Dark and Weisbach 1991). Rome was no exception and there was a tendency for public authorities to constrain paternal authority and to intervene more in private family disputes. Fathers' power of life and death (ius vitae necisque) over children, initially only constrained by reputation and the custom of consulting a family council, started to be questioned - at least in some extraordinary cases - from the beginning of the second century C.E. (Nicholas 1962:66-69). It has also been argued that at some point fathers were allowed to impose harsh punishments on their children only under judicial supervision (Frier and McGin 2003:202-203).

44 Tutors were increasingly constrained in the way they could manage the property of their wards or pupils, especially after 195 C.E. In particular, tutors' restrictions on alienation may have delayed the optimal reallocation of resources (Kehoe 2013b). However, given the attachment to family property and considering that fraudulent alienations (as compared, for example, to fraudulent leases) would have been more costly for pupils, it is likely that most fathers would have voluntarily introduced a similar condition in their wills. If this is the case, rather than constraining, this rule in fact facilitated voluntary economic decisions for most economic actors. Moreover, if fathers could abrogate the rule by explicitly stipulating otherwise in their will-i.e., if it was a default instead of a mandatory rule-, the constraint would have had only second order effects. Lastly, in any case, part of the cost in terms of resource reallocation would be offset by the benefit of restraining inefficient transfers purely motivated by tutors' misbehavior. 
contracting (a more private engagement and a more public wedding) and elaborate public ceremonies and dowry (Crook 1967:102-103, Arruñada 2012:238-39 n. 14, Hersch 2010); but also adoption, which was commonly used to achieve succession by adopting adults who came under the power of their adoptive fathers; emancipation, which led to the dissolution of parental authority, and was often used as a sanction; and the purchase and manumission of slaves. As with any mancipatio, some marriages, adoption, emancipation and manumission were ceremonial and required the presence of witnesses (Crook 1967:107-13, Nicholas 1962:71-80, Scafuro 2013), who often played a purging function. Some adoptions were even subject to public supervision: in particular, adoption of a person not under the power of another man often produced the merger of two families, making public approval advisable, not only because it extinguished a family (Nicholas 1962:77) but possibly because it may have had serious consequences for third parties, mainly creditors. In fact, the very prevalence of adoption in Rome, by indicating the extraordinary importance of succession, indirectly supports the argument as to the contractual-entity nature of the family.

These requirements of publicity are understandable considering that legal acts establishing or modifying individuals' status, such as birth, ${ }^{45}$ emancipation, adoption, marriage, manumission, etc., may have had serious consequences for subsequent transactions in which the status of the individuals or their children was a key condition for their legal effects. For example, marriage determined the status of children, and adoption affected the right to inherit and the power of the adopted to commit the household head. The consequences of slavery and manumission were similarly important, as slavery made a form of contractual agency viable and manumission gave the right to marry and have freeborn children (Crook 1967:52). ${ }^{46}$

\section{Concluding remarks}

The degree of specialization and the extent of Roman markets are indicative of extensive impersonal exchange, which was supported by an array of sophisticated public institutions. The Roman state not only enacted legal rules suitable for impersonal and distant trade, such as those on land conveyance, business agency, and self-help; but also co-opted traditional social solutions taken, for instance, from family law to enable the extended family to act as an effective contractual entity in economic matters.

45 The birth registry was voluntary, but (as often happens with public registries) people were motivated to record to enjoy legal effects (Rowlandson 2013). The evidence can be interpreted as confirming the argument: entry in a preliminary record or kalendarium was declarative, without any check of its accuracy, and in principle illegitimate children (with fewer or no rights) were not included in a wooden album, which suggests some form of purge, especially considering that the album was publicly displayed, with both archives working respectively as a mere recording diary and as a proper register with greater effects on third parties. It is consistent with this interpretation that the copies used as proof of status were produced from the album and were authenticated by up to seven witnesses.

46 See a case in Crook (1967:48-49). 
This paper provides a novel interpretation of these institutions within a coherent analytical framework. Impersonal exchange, being based on property rights enforced on assets without the need for information about trading partners, avoids relying on personal safeguards that may act as entry barriers (including reputation and expectations of future trade). It therefore expands trade and specialization opportunities, fostering economic growth.

This focus on the institutions of impersonal exchange allows the paper to draw a clear positive conclusion on the market-enabling role of the Roman state because such institutions have unambiguously positive effects on markets. Moreover, these beneficial effects, being impersonal, are also widely distributed across society. Instead of advancing only the interests of the elite - as institutions favoring personal exchange tend to do-institutions favoring impersonal exchange not only expand markets but can be considered a paradigm for institutions favoring an "open access" (North, Wallis and Weingast 2009) and "inclusive" (Acemoglu and Robinson 2012) social order.

\section{References}

Abatino, Barbara, and Giuseppe Dari-Mattiacci. Forthcoming. "Agency Problems and Organizational Costs in Slave-run Business." In Giuseppe Dari-Mattiacci, ed., Roman Law and Economics, vol. 1: Ch. 10. Oxford Studies in Roman Society and Law (Tom McGinn and Paul Du Plessis, eds.). Oxford: Oxford University Press.

Abatino, Barbara, Giuseppe Dari-Mattiacci, and Enrico C. Perotti. 2011. "Depersonalization of Business in Ancient Rome." Oxford Journal of Legal Studies 31:365-89.

Acemoglu, Daron, and James A. Robinson. 2012. Why Nations Fail: The Origins of Power, Prosperity and Poverty. New York: Crown Publishers.

Andreau, Jean. 1999. Bankers and Business in the Roman World. Cambridge: Cambridge University Press.

Arruñada, Benito, Luis Garicano, and Luis Vázquez. 2001. "Contractual Allocation of Decision Rights and Incentives: The Case of Automobile Distribution.” Journal of Law, Economics, and Organization 17:256-83.

Arruñada, Benito. 2003. "Property Enforcement as Organized Consent." Journal of Law, Economics, and Organization 19:401-44.

Arruñada, Benito. 2010. "Institutional Support of the Firm: A Theory of Business Registries." The Journal of Legal Analysis 2:525-76.

Arruñada, Benito. 2012. Institutional Foundations of Impersonal Exchange: Theory and Policy of Contractual Registries. Chicago and London: University of Chicago Press.

Arruñada, Benito. 2015. "The Titling Role of Possession." In Yun-chien Chang, ed., The Law and Economics of Possession:207-33. Cambridge: Cambridge University Press.

Arruñada, Benito. Forthcoming. "The Institutions of Roman Markets." In Giuseppe DariMattiacci, ed., Roman Law and Economics, vol. 2: Ch. 17. Oxford Studies in Roman Society and Law (Tom McGinn and Paul Du Plessis, eds.). Oxford: Oxford University Press. 
Arruñada, Benito. 2016. "Coase and the Departure from Property." In Claude Ménard and Elodie Bertrand, eds., The Elgar Companion to Ronald H. Coase: 305-19. Cheltenham UK: Elgar.

Aubert, Jean-Jacques. 1994. Business Managers in Ancient Rome: A Social and Economic Study of Institors, 200 B.C.-A.D. 250. Leiden: E.J. Brill.

Aubert, Jean-Jacques. 2013. “Institor.” In Roger S. Bagnall, Kai Brodersen, Craige B. Champion, Andrew Erskine, and Sabine R. Huebner, eds., The Encyclopedia of Ancient History, First Edition:3466-67. Malden, MA; Oxford: Wiley-Blackwell.

Bang, Peter F. 2008. The Roman Bazaar: A Comparative Study of Trade and Markets in a Tributary Empire. Cambridge: Cambridge University Press.

Berman, Harold J. 1983. Law and Revolution: The Formation of the Western Legal Tradition. Cambridge: Harvard University Press.

Bransbourg, Gilles. 2012. "Rome and the Economic Integration of Empire." Institute for the Study of the Ancient World Papers 3. http://dlib.nyu.edu/awdl/isaw/isaw-papers/3/ (visited July 30, 2015).

Bransbourg, Gilles. 2014. "Les taux d'intérêt flottants des Sulpicii." In Catherine Apicella, Marie-Laurence Haack, and François Lerouxel, eds., Les affaires de Monsieur Andreau: Économie et société du monde romain:123-35. Bordeaux: Ausonius.

Brickley, James A, Frederick H. Dark and Michael S. Weisbach. 1991. "The Economic Effects of Franchise Termination Laws." Journal of Law and Economics 34(1):101-32.

Brown, Peter. 1971. The World of Late Antiquity AD 150-750. London: Thames \& Hudson. (Reprint 2006).

Bürge, Alfons. 1980. "Vertrag und personale Abhängigkeiten im Rom der späten Republik und der frühen Kaiserzeit." Zeitschrift der Savigny-Stiftung für Rechtsgeschichte: Romanistische Abteilung 97:105-56.

Crook, John A. 1967. Law and Life of Rome. Ithaca, NY: Cornell University Press.

Dari-Mattiacci, Giuseppe. 2013. "Slavery and Information," The Journal of Economic History 73:79-116.

de Vos Raaijmakers, Mariette. 2013. "The Rural Landscape of Thugga: Farms, Presses, Mills, and Transport." In Alan Bowman and Andrew Wilson, eds., The Roman Agricultural Economy: Organization, Investment, and Production, 143-218. Oxford: Oxford University Press.

Djankov, Simeon, Rafael La Porta, Florencio Lopez-de-Silanes, and Andrei Shleifer. 2008, "The Law and Economics of Self-Dealing." Journal of Financial Economics 88:430-65.

Ellickson, Robert C. Forthcoming. "Ancient Rome: Legal Foundations of the Growth of an Indispensible City." In Giuseppe Dari-Mattiacci, ed., Roman Law and Economics, vol. 2: Ch. 15. Oxford Studies in Roman Society and Law (Tom McGinn and Paul Du Plessis, eds.). Oxford: Oxford University Press.

Erdkamp, Paul. 2005. The Grain Market in the Roman Empire: A Social, Political and Economic Study. Cambridge: Cambridge University Press.

Finley, Moses I. 1999. The Ancient Economy, Berkeley: University of California Press.

Frier, Bruce W., and Thomas A. McGin. 2003. A Casebook on Roman Family Law. New York: Oxford University Press. 
Gaius. 170. The Institutes of Gaius. Translation, Edward Poste. Revision, E.A. Whittuck. Oxford: Clarendon Press, 1904.

Gibbs, Matt. 2013. "Tax Farming.” In Roger S. Bagnall, Kai Brodersen, Craige B. Champion, Andrew Erskine, and Sabine R. Huebner, eds., The Encyclopedia of Ancient History, First Edition:6553-55. Malden, MA; Oxford: Wiley-Blackwell.

Greene, Kevin. 2000. "Technical Innovation and Economic Progress in the Ancient World: M. I. Finley Re-Considered.” Economic History Review 53:29-59.

Hansmann, Henry, and Reinier Kraakman. 2000. "The Essential Role of Organizational Law." Yale Law Journal 110:387-440.

Hansmann, Henry, and Reinier Kraakman. 2002. "Property, Contract, and Verification: The Numerus Clausus Problem and the Divisibility of Rights." Journal of Legal Studies 31:S373S420.

Hansmann, Henry, Reinier Kraakman, and Richard Squire. 2006. "Law and the Rise of the Firm." Harvard Law Review 119:1333-403.

Harris, Ron. 2000. Industrializing English Law: Entrepreneurship and Business Organization, 1720-1844. Cambridge: Cambridge University Press.

Heather, Peter. 2005. The Fall of the Roman Empire: A New History. London: Macmillan.

Heller, Michael A. 1999. “The Boundaries of Private Property.” Yale Law Journal 108:1163223.

Hersch, Karen K. 2010. The Roman Wedding: Ritual and Meaning in Antiquity. Cambridge: Cambridge University Press.

Johnson, Simon, Rafael La Porta, Florencio Lopez-de-Silanes, and Andrei Shleifer. 2000. "Tunneling." American Economic Review Papers and Proceedings 90:22-27.

Johnson, Noel D., and Mark Koyama. 2014. "Tax Farming and the Origins of State Capacity in England and France." Explorations in Economic History 51:1-20.

Johnston, David. 1999. Roman Law in Context. Cambridge: Cambridge University Press.

Kaser, Max. 1971 (1955-1959). Das römische Privatrecht, I 2nd ed. HdA X.3.3.1. Munich: Beck.

Kehoe, Dennis P. 2013a. "The State and Production in the Roman Agrarian Economy." In Alan K. Bowman and Andrew I. Wilson, eds., The Roman Agricultural Economy: Organisation, Investment and Production:33-53. Oxford: Oxford University Press.

Kehoe, Dennis P. 2013b. "Law, Agency, and Growth in the Roman Economy." In Paul J. Du Plessis, ed., New Frontiers: Law and Society in the Roman World:177-91. Edinburgh: University of Edinburgh Press.

Kehoe, Dennis P. Forthcoming. "Mandate and the Management of Business in the Roman Empire." In Giuseppe Dari-Mattiacci, ed., Roman Law and Economics, vol. 1: Ch. 11. Oxford Studies in Roman Society and Law (Tom McGinn and Paul Du Plessis, eds.). Oxford: Oxford University Press.

Kessler, David, and Peter Temin. 2007. "The Organization of the Grain Trade in the Early Roman Empire." Economic History Review 60:313-32.

Kirschenbaum, Aaron. 1987. Sons, Slaves and Freedmen in Roman Commerce. Jerusalem: The Hebrew University Magnes Press. 
Koyama, Mark. 2010. 'Evading the 'Taint of Usury:' The Usury Prohibition as a Barrier to Entry." Explorations in Economic History 47(4):420-42.

Lerouxel, François. 2012a. "The Private Credit Market, the Bibliotheke Enkteseon, and Public Services in Roman Egypt." Annales. Histoire, Sciences Sociales 67(4):629-59.

Lerouxel, François. 2012b. "Des prêts sans intérêt? Le taux d'intérêt dans le nome oxyrhynchite avant 79." Zeitschrift für Papyrologie und Epigraphik 181:161-172.

Levitin, Adam J. 2013. "The Paper Chase: Securitization, Foreclosure, and the Uncertainty of Mortgage Title." Duke Law Journal 63(3):637-734.

Lo Cascio, Elio. Forthcoming. "Setting the Rules of the Game: The Market and Its Working in the Roman Empire." In Giuseppe Dari-Mattiacci, ed., Roman Law and Economics, vol. 1: Ch. 5. Oxford Studies in Roman Society and Law (Tom McGinn and Paul Du Plessis, eds.). Oxford: Oxford University Press.

Livy. 2004. The History of Rome, Books 27 to 36. Translator, Cyrus R. Edmonds. http://www.gutenberg.org/ebooks/12582 (visited December 1, 2013).

Malmendier, Ulrike. 2009, "Law and Finance 'at the Origin'." Journal of Economic Literature 47:1076-108.

Merrill, Thomas W., and Henry E. Smith. 2000. "Optimal Standardization in the Law of Property: The Numerus Clausus Principle.” Yale Law Journal 110:1-70.

Meyer, Elizabeth A. 2004. Legitimacy and Law in the Roman World: Tabulae in Roman Belief and Practice. Cambridge: Cambridge University Press.

Monson, Andrew. 2012. From the Ptolemies to the Romans. Political and Economic Change in Egypt. Cambridge: Cambridge University Press.

Nicholas, Barry. [1962] 2010. An Introduction to Roman Law. Oxford: Oxford University Press.

North, Douglass C. 1990. Institutions, Institutional Change and Economic Performance. Cambridge: Cambridge University Press.

North, Douglass C., John Joseph Wallis, and Barry R. Weingast. 2009. Violence and Social Orders: A Conceptual Framework for Interpreting Recorded Human History. Cambridge: Cambridge University Press.

Parker, Anthony John. 1992. Ancient Shipwrecks of the Mediterranean and the Roman Provinces. British Archaeological Reports International Series 580. Oxford: Tempus Reparatum.

Petrucci, Aldo. 2003. "Orígenes romanísticos de la buena fe objetiva en la contratación mercantil." Anuario Mexicano de Historia del Derecho 15:601-15.

Ramin, Jacques, and Paul Veyne. 1981. "Droit romain et société: Les hommes libres qui passent pour esclaves et l'esclavage volontaire." Historia 30:472-97.

Rathbone, Dominic. 1991. Economic Rationalism and Rural Society in Third-Century A. D. Egypt: The Heroninos Archive and the Appianus Estate. Cambridge: Cambridge University Press.

Riggsby, Andrew M. 2010. Roman Law and the Legal World of the Romans. Cambridge: Cambridge University Press.

Rose, Carol M. 1985. "Possession as the Origin of Property." University of Chicago Law Review $52: 73-88$. 
Rose, Carol M. 1988. "Crystals and Mud in Property Law." Stanford Law Review 40:577-610.

Rowlandson, Jane. 1981. "Sales of Land in Their Social Context.” In Roger S. Bagnall, Gerald Browne, Ann E. Hanson and Ludwig Koenen, eds., Proceedings of the Sixteenth International Congress of Papyrology:371-78. New York: Chico Scholars Press.

Rowlandson, Jane. 2013. "Birth, Registrations of." In Roger S. Bagnall, Kai Brodersen, Craige B. Champion, Andrew Erskine, and Sabine R. Huebner, eds., The Encyclopedia of Ancient History, First Edition:1128-31. Malden, MA; Oxford: Wiley-Blackwell.

Sánchez-Moreno Ellart, Carlos. 2013. “Archives.” In Roger S. Bagnall, Kai Brodersen, Craige B. Champion, Andrew Erskine, and Sabine R. Huebner, eds., The Encyclopedia of Ancient History, First Edition:660-65. Malden, MA; Oxford: Wiley-Blackwell.

Scafuro, Adele C. 2013. "Witnesses, Greek and Roman.” In Roger S. Bagnall, Kai Brodersen, Craige B. Champion, Andrew Erskine, and Sabine R. Huebner, eds., The Encyclopedia of Ancient History, First Edition:7114-16. Malden, MA; Oxford: Wiley-Blackwell.

Scheidel, Walter, and Steven J. Friesen. 2009. "The Size of the Economy and the Distribution of Income in the Roman Empire." Journal of Roman Studies 99:61-91.

Scheidel, Walter. 2008. "The Comparative Economics of Slavery in the Greco-Roman World." In Enrico Dal Lago and Constantina Katsari, eds., Slave Systems, Ancient and Modern:10526. Cambridge: Cambridge University Press.

Scheidel, Walter. 2012. "Approaching the Roman Economy.” In Walter Scheidel, ed., The Cambridge Companion to the Roman Economy:1-21. Cambridge: Cambridge University Press.

Scheidel, Walter. 2013. "The Shape of the Roman World.” Princeton/Stanford Working Papers in Classics. Version 1.0. April.

Schulz, Fritz. 1951. Classical Roman Law. Oxford: Clarendon Press.

Smith, Henry E. 2006. "Modularity in Contracts: Boilerplate and Information Flow." University of Michigan Law Review 104:1175-222.

Smith, Henry E. 2009. "Modularity in Property, Intellectual Property, and Organizations." Harvard Law School Working Paper, September 17.

Tacitus. 2005. The Reign of Tiberius, Out of the First Six Annals of Tacitus; With His Account of Germany, and the Life of Agricola. Translator, Thomas Gordon. Editor, Arthur Galton. http://www.gutenberg.org/ebooks/7959 (visited December 1, 2013).

Temin, Peter. 2006. "The Economy of the Early Roman Empire." Journal of Economic Perspectives 20:133-51.

Temin, Peter. 2013. The Roman Market Economy. Princeton: Princeton University Press.

Verboven, Koenraad. 2002. The Economy of Friends: Economic Aspects of Amicitia and Patronage in the Late Republic. Brussels: Latomus.

Verboven, Koenraad. 2003. "The Sulpicii from Puteoli and Usury in the Early Roman Empire." Tijdschrift voor Rechtsgeschiedenis 71:7-28.

Verboven, Koenraad. 2013. “Clientela, Roman Republic.” In Roger S. Bagnall, Kai Brodersen, Craige B. Champion, Andrew Erskine, and Sabine R. Huebner, eds., The Encyclopedia of Ancient History, First Edition:1577-82. Malden, MA; Oxford: Wiley-Blackwell. 
Verhagen, Hendrik L.E. Forthcoming. "The Security of Credit in Rome: Secured Transactions in Classical Roman Law." In Giuseppe Dari-Mattiacci, ed., Roman Law and Economics, vol. 2: Ch. 14. Oxford Studies in Roman Society and Law (Tom McGinn and Paul Du Plessis, eds.). Oxford: Oxford University Press.

Wacke, A. 1994. "Die adjektizischen Klagen im Überblick.” Zeitschrift der Savigny-Stiftung für Rechtsgeschichte: Romanistische Abteilung 111: 280-362.

Ward-Perkins, Bryan. 2005. The Fall of Rome and the End of Civilization. Oxford: Oxford University Press.

Williamson, Oliver E. 1991. "Comparative Economic Organization: The Analysis of Discrete Structural Alternatives.” Administrative Sciences Quarterly 36:269-96.

Wilson, Andrew I. 2011. "City Sizes and Urbanization in the Roman Empire." In Alan K. Bowman, and Andrew I. Wilson, eds., Settlement, Urbanization, and Population, 161-95: Oxford: Oxford University Press.

Winkel, Laurens. 2013. "Ius Gentium.” In Roger S. Bagnall, Kai Brodersen, Craige B. Champion, Andrew Erskine, and Sabine R. Huebner, eds., The Encyclopedia of Ancient History, First Edition:3553-54. Malden, MA; Oxford: Wiley-Blackwell.

Zimmermann, Reinhard. 1996. The Law of Obligations: Roman Foundations of the Civilian Tradition. Oxford: Oxford University Press. 